\title{
Variasi Musiman Hubungan Antara Parameter Oceanografi Dengan Hasil Tangkapan Ikan Tongkol Berdasarkan Data Harian Di Selat Bali
}

\author{
I Gusti Agung Bagus Wisesa Sastra a*, I Wayan Gede Astawa Karang a, \\ Abd. Rahman As-syakur a, Yulianto Suteja a \\ a Program Studi Ilmu Kelautan, Fakultas Kelautan dan Perikanan, Universitas Udayana, Kampus UNUD Bukit Jimbaran, Bali 80361, Indonesia \\ * Penulis koresponden. Tel.: +62-896-226-843-21 \\ Alamat e-mail: wisesa_sastra@yahoo.co.id
}

Diterima (received) 17 Juli 2017; disetujui (accepted) 6 September 2017; tersedia secara online (available online) 7 September

\begin{abstract}
Mackerel fish that classified pelagic fish and an export commodity in Indonesia. Distribution of mackerel fish are found in all Indonesian waters, one of them in the Bali Strait. Distribution of mackerel fish influenced by oceanographic condition such as sea surface temperature (SST) and chlorophyll-a concentration. SST and chlorophylla concentrations are environmental parameters that can provide information on fishing ground. The purpose of this research is explained the temporal fluctuation and relationship between SST and chlorophyll-a concentration with mackerel fish had been catch in Bali Strait waters during 2011-2016. Data were analyzed using simple correlation analysis with 95\% confidence interval. Temporally, the highest average SST occurred during the transition season I (March-May) and the lowest in the east season (June-August). The highest average chlorophyll-a concentration occurs in the east season and the lowest in the west season (December-February). The highest catch of mackerel fish occurred during transitional season II (September-November) and lowest in west season. The association between SST and chlorophyll-a concentration on mackerel fish catch showed low correlation with significant relationship, whereas concentration between SST and chlorophyll-a concentration strong with significant correlation.
\end{abstract}

Keywords : mackerel fish; Bali Strait; sea surface temperature; chlorophyll-a; aqua modis

\begin{abstract}
Abstrak
Ikan tongkol merupakan jenis ikan pelagis dan menjadi komuditas ekspor di Indonesia. Persebaran ikan tongkol ditemukan hampir di seluruh perairan Indonesia, salah satunya pada perairan Selat Bali. Sebaran ikan tongkol dipengaruhi oleh kondisi oseanografi yaitu suhu permukaan laut (SPL) dan konsentrasi klorofil-a. SPL dan konsentrasi klorofil-a merupakan parameter lingkungan yang dapat memberikan informasi daerah penangkapan ikan. Tujuan dari penelitian ini untuk mengetahui fluktuasi dan hubungan secara temporal antara SPL dan konsentrasi klorofil-a terhadap tangkapan ikan tongkol di perairan Selat Bali pada tahun 2011-2016. Data dianalisis menggunakan analisis korelasi sederhana dengan selang kepercayaan 95\%. Secara temporal, rata-rata SPL tertinggi terjadi pada musim peralihan I (Maret-Mei) dan terendah pada musim timur (Juni-Agustus). Rata-rata konsentrasi klorofil-a tertinggi terjadi pada musim timur dan terendah pada musim barat (Desember-Februari). Rata-rata tangkapan ikan tongkol tertinggi terjadi pada musim peralihan II (September-November) dan terendah pada musim barat. Hubungan antara SPL dan konsentrasi klorofil-a terhadap tangkapan ikan tongkol menunjukkan korelasi rendah dengan hubungan yang signifikan, sedangkan antara SPL terhadap konsentrasi klorofil-a menunjukkan korelasi kuat dengan hubungan yang signifikan.
\end{abstract}

Kata Kunci: ikan tongkol; Selat Bali; suhu permukaan laut; klorofil-a; aqua modis 


\section{Pendahuluan}

Ikan tongkol merupakan biota laut pemakan daging (carnivor) yang membentuk gerombolan dengan kemampuan renang yang cepat di dalam perairan (Zarochman, 2012; Ferraro et al., 2013). Ikan tongkol merupakan salah satu jenis ikan pelagis yang menjadi komuditas ekspor Indonesia (Mujib et al., 2013). Ikan tongkol merupakan target tangkapan hasil perikanan bagi nelayan yang memiliki nilai ekonomis bagi sumberdaya perikanan (Akhlak et al., 2015). Persebaran ikan tongkol di perairan hampir berada pada seluruh perairan Indonesia, salah satunya berada pada perairan Selat Bali.

Perairan Selat Bali merupakan wilayah perairan yang unik dan dinamis (Pratiwi et al., 2017). Jenis potensi sumberdaya ikan utama pada kegiatan tangkapan ikan pelagis di perairan Selat Bali, terdapat jenis ikan kembung, layang, lemuru, dan salah satunya adalah ikan tongkol (Sartimbul et al., 2010). Hasil tangkapan ikan tongkol di perairan Selat Bali mencapai $1.632 .383 \mathrm{~kg}$ pada tahun 2015 (Prayoga et al., 2017). Dalam melakukan penangkapan ikan, informasi mengenai daerah tangkapan sangatlah penting untuk meningkatkan efektifitas penangkapan. Informasi daerah penangkapan dapat diperoleh melalui parameter oseanografi. Menurut Adnan (2010) variabilitas hasil tangkapan ikan disuatu perairan dipengaruhi oleh parameter oseanografi yaitu suhu permukaan laut (SPL).

SPL merupakan faktor penting bagi kehidupan organisme dalam aktivitas perkembangan metabolisme (Tangke et al., 2015). Kisaran suhu tertentu yang berada disuatu perairan dapat mempengaruhi penyebaran ikan di perairan tersebut. Selain SPL yang dapat mempengaruhi hasil tangkapan ikan tongkol disuatu perairan, ada juga faktor oseanografi lain yaitu konsentrasi klorofil.

Konsentrasi klorofil merupakan pigmen hijau fitoplankton yang diperlukan dalam proses fotosintesis. Menurut Putri et al., (2016) klorofil-a dapat menggambarkan kelimpahan fitoplankton disuatu perairan. Menurut Nybakken (1992) keberadaan fitoplankton diperairan akan dimanfaatkan oleh zooplankton, dimana saat adanya zooplankton akan mempengaruhi keberadaan ikan.

Penelitian di perairan laut yang menggunakan metode konvensional sudah banyak dilakukan terhadap sebaran SPL dan konsentrasi klorofil-a.
Akan tetapi, jika menggunakan metode konvensional pada suatu penelitian diperlukannya diperlukannya durasi waktu yang lama dengan biaya yang tinggi. Teknologi yang semakin berkembang memudahkan untuk mendapatkan informasi yang banyak dan akurat. Salah satu teknologi yang digunakan untuk mengetahui sebaran SPL dan konsentrasi klorofil-a adalah penginderaan jauh (remote sensing). Satelit penginderaan jauh yang dapat mendeteksi SPL dan konsentrasi klorofil-a pada perairan adalah satelit Aqua Moderate Resolution Imaging Spectroradiometer (MODIS) (Ashari et al., 2014).

Satelit Aqua MODIS mempunyai fungsi untuk mengumpulkan informasi tentang siklus air di bumi yang dimiliki oleh NASA. Aqua MODIS dapat mengukur variabel seperti tumbuhan yang menutupi daratan, fitoplankton, bahan organik terlarut, suhu di laut dan daratan. Sensor Aqua MODIS memiliki 36 kanal spectral. Penggunaan satelit ini biasanya dikhususkan pada pengamatan laut dan atmosfer. Sifat datanya yang gratis dan mudah proses pengunduhannya, membuat banyak orang yang melakukan penelitian di bidang kelautan untuk memanfaatkan data ini. Selain itu, data pengamatan lapangan yang tersedia secara gratis di internet didapatkan dari citra penginderaan jauh. Salah satunya adalah data yang dapat di unduh pada wibe site http:// www.oceancolor.gsfc.nasa.gov.

Banyak penelitian sebelumnya mengkaji tentang informasi antara SPL dan konsentrasi klorofil-a terhadap hasil tangkapan ikan. Diantaranya adalah kajian mengenai pemetaan daerah penangkapan ikan tuna mata besar di selatan Jawa dan Bali oleh Padmaningrat et al. (2017), hubungan hasil tangkapan ikan tuna dengan konsentrasi klorofil-a dan SPL oleh Ekayana et al. (2017) dan pengaruh sebaran konsentrasi klorofil-a dengan hasil tangkapan ikan tongkol (Euthynnus sp) di perairan Selat Bali oleh Prayoga et al. (2017). Kajian tentang informasi antara SPL dan klorofil-a tersebut dilakukan dengan menggunakan data bulanan level 3.

Penggunaan data bulanan level 3 memiliki kelemahan dalam perekaman data di wilayah yang kecil seperti perairan Selat Bali. Hal ini dikarenakan resolusi spasial yang tertinggi hanya mencapai sebesar $4 \mathrm{~km}$, maka dikarenakan hal tersebut dalam penelitian ini digunakannya data harian atau data level 2 dengan resolusi spasial 1 $\mathrm{km}$ agar mendapatkan data yang lebih akurat," 

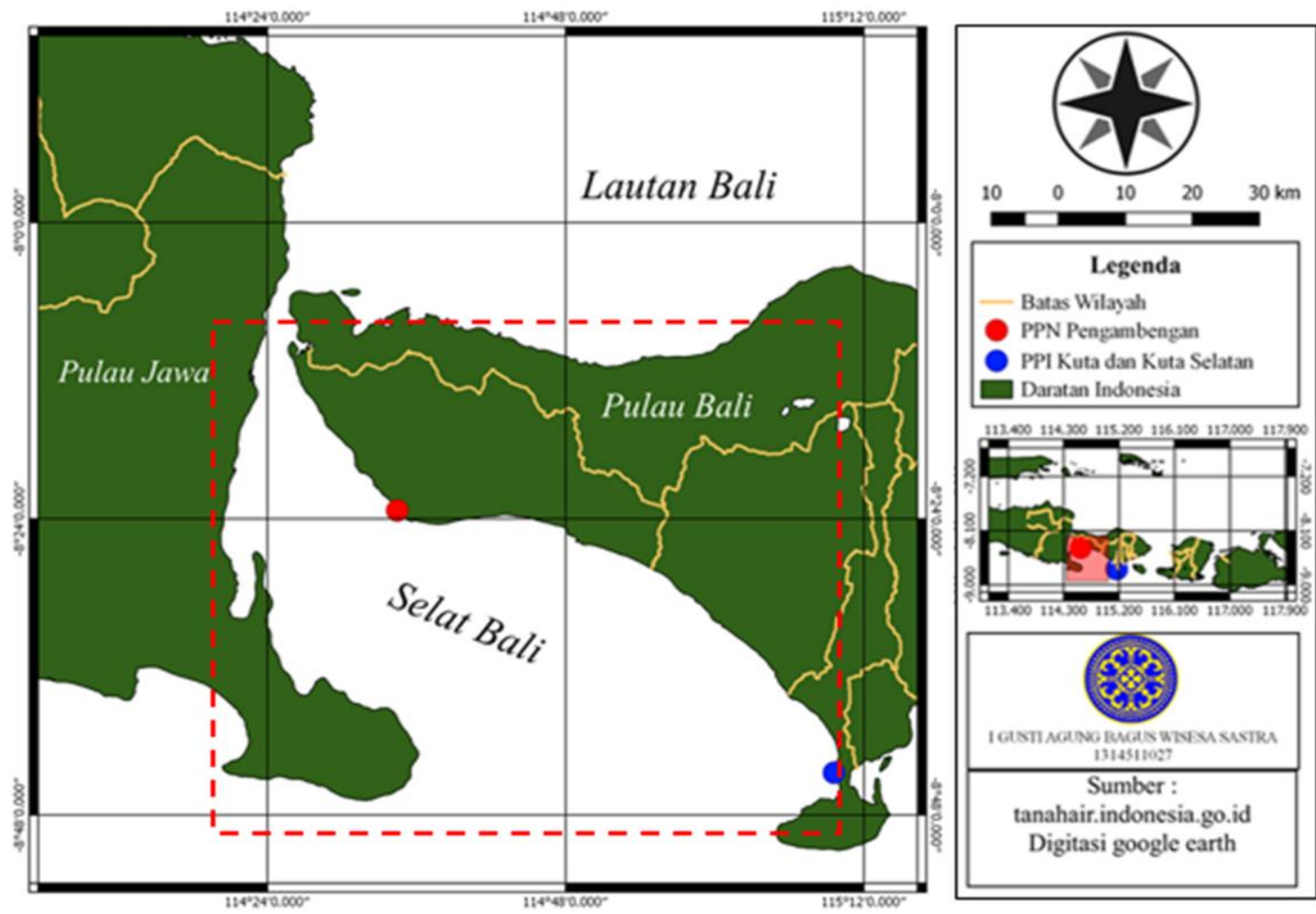

Gambar 1. Peta Lokasi Penelitian di Perairan Selat Bali

dimana SPL dan konsentrasi klorofil-a merupakan indikator yang mempengaruhi hasil tangkapan ikan. Tujuan penelitian ini adalah untuk mengetahui fluktuasi dan hubungan secara temporal antara hasil tangkapan ikan tongkol dengan SPL dan konsentrasi klorofil-a di perairan Selat Bali pada tahun 2011-2016 dengan menggunakan data harian hasil tangkapan maupun data citra satelitnya.

\section{Metode Penelitian}

Menggunakan metode deskriptif-kuantitatif. Metode deskriptif adalah suatu metode yang menggambarkan objek penelitian berdasarkan fakta-fakta sebagaimana adanya, kemudian dianalisis, sedangkan metode kuantitatif merupakan metode penelitian yang menjelaskan dan diinterpretasikan dalam suatu uraian dalam bentuk data berupa angka-angka.

\subsection{Waktu dan Tempat Penelitian}

Pelaksanaan penelitian ini dimulai dari bulan Maret 2017 sampai dengan bulan Juni 2017. Penelitian ini dilaksanakan di perairan Selat Bali yang terletak pada koordinat $8,16^{\circ} \mathrm{LS}$ sampai $8,80^{\circ} \mathrm{LS}$ dan $114,3^{\circ} \mathrm{BT}$ sampai $115,2^{\circ} \mathrm{BT}$ (Gambar 1).

\subsection{Alat dan Data Penelitian}

Penelitian ini menggunakan beberapa alat diantaranya adalah Software SeaDas 7.4, software SAGA 2.3.1, Software Quantum GIS dan Software ArtGIS 10.3 yang berfungsi untuk mengolah data citra Aqua MODIS level 2. Penelitian ini menggunakan data hasil tangkapan ikan tongkol dari Pelabuhan Perikanan Nusantara (PPN) Pengambengan dan Pangkalan Pendaratan Ikan (PPI) Kuta dan Kuta Selatan. Data sebaran SPL dan konsentrasi klorofil-a pada perairan Selat Bali didapat dari http://www.oceancolor.gsfc.nasa.gov yang berupa data harian level 2 dengan resolusi 1x1 km² di bulan Januari 2011 - Desember 2016. Pemilihan citra level 2 dilakukan karena pada level ini citra sudah terkoreksi secara radiometrik.

\subsection{Analisis Data}

2.3.1 Analisis Data SPL dan Konsentrasi Klorofil-a dan Tangkapan Ikan Tongkol

Data harian SPL dan konsentrasi klorofil-a yang diunduh pada wibe site http:// www.oceancolor.gsfc.nasa.gov. kemudian dijadikan dalam bentuk rata-rata bulanan. Rata- 
rata bulanan dikarenakan data harian tersebut tidak maksimal bila digunakan untuk analisis obyek bumi secara global karena banyaknya tutupan awan sehingga dilakukan seleksi citra harian dengan liputan awan minimum dan diakumulasikan menjadi rata-rata bulanan dan musiman (Nuris, 2014). Pada data tangkapan ikan tongkol, hasil tangkapan dijumlahkan dalam bentuk bulanan. Data dianalisis menggunakan korelasi sederhana. Menurut Walpole (1995) menyatakan bahwa korelasi product moment/sederhana (persamaan 1).

$$
r=\frac{n \sum x_{i} y-\left(\sum x_{i}\right)\left(\sum y\right)}{\sqrt{\left(n \sum x_{i}^{2}-\left(\sum x_{i}\right)^{2}\right)\left(n \sum y_{i}^{2}-\left(\sum y_{i}\right)^{2}\right)}}
$$

Berikut ini adalah keterangan dari persamaan 1, dimana $\mathrm{r}$ adalah nilai koefisien korelasi; $\mathrm{n}$ adalah jumlah data; y adalah jumlah tangkapan ikan tongkol dan $x$ adalah parameter oseanografi (SPL dan konsentrasi klorofil-a).

Penentuan korelasi antara 2 varibel memiliki kategori masing-masing. Koefisien korelasi antara SPL dan konsentrasi klorofil-a terhadap hasil tangkapan ikan tongkol yang diperoleh, kemudian diuji validitasinya dengan membandingkan nilai $r$ hitung ( $\mathrm{r}$ ) terhadap tabel $\mathrm{r}$ product moment 5\% (selang kepercayaan 95\%).

- Dasar pengambilan keputusan pengujian :

- Jika $r$ hitung > r tabel maka $\mathrm{H}_{0}$ ditolak dan menerima $\mathrm{H} 1$

- Jika $\mathrm{r}$ hitung $<\mathrm{r}$ tabel maka $\mathrm{H}_{0}$ diterima dan menolak H1

- Hipotesis yang diuji dalam penelitian ini adalah sebagai berikut :

- HO = Tidak ada hubungan signifikan antara 2 variabel

- $\mathrm{H1}=$ Ada hubungan signifikan antara 2 variabel

\section{Hasil dan Pembahasan}

3.1 Fluktuasi SPL, Konsentrasi Klorofil-a dan Hasil Tangkapan Ikan Tongkol pada Perairan Selat Bali Tahun 2011-2016

3.1.1 Fluktuasi Temporal SPL di Perairan Selat Bali Tahun 2011-2016

Selat Bali merupakan suatu wilayah perairan yang dipengaruhi oleh kondisi oseanografi salah satunya SPL musiman. Pada musim peralihan I (Maret-Mei) menunjukkan nilai rata-rata SPL tertinggi, sedangkan rata-rata SPL pada musim timur (Juni-Agustus) menunjukkan nilai terendah. Variabiltas temporal SPL di perairan Selat Bali tahun 2011-2016 ditampilkan pada Gambar 3.

Pada musim barat tahun 2011-2016, nilai SPL bulan Januari berkisar $27.55^{\circ}-31.06^{\circ} \mathrm{C}$ dengan nilai rata-rata sebesar $29.54^{\circ} \mathrm{C}$, nilai SPL pada bulan Februari berkisar $28.790-31.13^{\circ} \mathrm{C}$ dengan nilai ratarata sebesar $29.91^{\circ} \mathrm{C}$ dan nilai SPL pada bulan Desember berkisar $27.96^{0}-30.73^{\circ} \mathrm{C}$ dengan nilai rata-rata sebesar $29.64^{\circ} \mathrm{C}$. Nilai rata-rata SPL pada musim barat tahun 2011-2016 sebesar 29.69 C.

Pada musim peralihan I tahun 2011-2016, nilai SPL bulan Maret berkisar 29.330-32.06 $\mathrm{C}$ dengan nilai rata-rata sebesar $30.44^{\circ} \mathrm{C}$, nilai SPL pada bulan April berkisar $28.56^{0}-31.45^{\circ} \mathrm{C}$ dengan nilai rata-rata sebesar $29.73^{\circ} \mathrm{C}$ dan nilai SPL pada bulan Mei berkisar $27^{0}-30.41^{\circ} \mathrm{C}$ dengan nilai rata-rata sebesar $29.01^{\circ} \mathrm{C}$. Nilai rata-rata SPL pada musim peralihan I tahun $2011-2016$ sebesar $29.73^{\circ} \mathrm{C}$.

Pada musim timur tahun 2011-2016, nilai SPL bulan Juni berkisar $26.25^{\circ}-30.44^{\circ} \mathrm{C}$ dengan nilai rata-rata sebesar $27.93^{\circ} \mathrm{C}$, nilai SPL pada bulan Juli berkisar $25.28^{\circ}-30.35^{\circ} \mathrm{C}$ dengan nilai rata-rata sebesar $26.94{ }^{\circ} \mathrm{C}$ dan nilai SPL pada bulan Agustus berkisar $25.23^{\circ}-28.27^{\circ} \mathrm{C}$ dengan nilai rata-rata sebesar $26.30^{\circ} \mathrm{C}$. Nilai rata-rata SPL pada musim timur tahun 2011-2016 sebesar $27.06^{\circ} \mathrm{C}$.

Pada musim peralihan II tahun 2011-2016, nilai SPL bulan September berkisar $25.27^{0}-28.73^{\circ} \mathrm{C}$ dengan nilai rata-rata sebesar $26.33^{\circ} \mathrm{C}$, nilai SPL pada bulan oktober berkisar $25.57^{\circ}-30.12^{\circ} \mathrm{C}$ dengan nilai rata-rata sebesar $27.26^{\circ} \mathrm{C}$ dan nilai SPL pada bulan November berkisar $26.92^{\circ}-30.76^{\circ} \mathrm{C}$ dengan nilai rata-rata sebesar $28.73^{\circ} \mathrm{C}$. Nilai rata-rata SPL pada musim peralihan II dari tahun 2011-2016 sebesar $27.49^{\circ} \mathrm{C}$.

SPL di perairan Selat Bali pada setiap musim selama tahun 2011-2016 mengalami fluktuasi (Gambar 2). Hal tersebut dikarenakan fluktuasi SPL pada setiap musimnya dipengaruhi oleh angin munson. Tingginya nilai rata-rata SPL pada musim peralihan I pada tahun 2011-2016, karena pada wilayah perairan Samudra Hindia berhembus angin munson barat laut dengan membawa arus pantai Jawa yang bersuhu tinggi bergerak ke timur disepanjang selatan Jawa-Bali (Ridha et al., 2013). Selain itu posisi matahari 


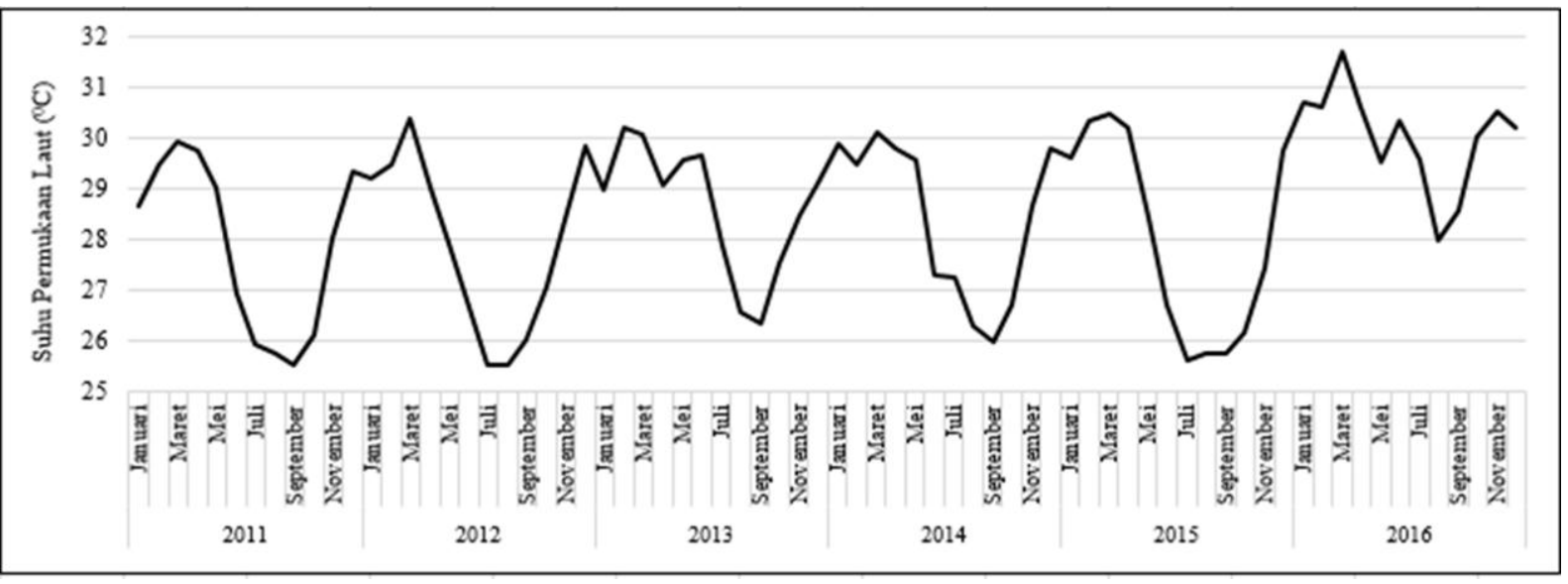

Gambar 2. Fluktuasi Temporal SPL pada tahun 2011-2016

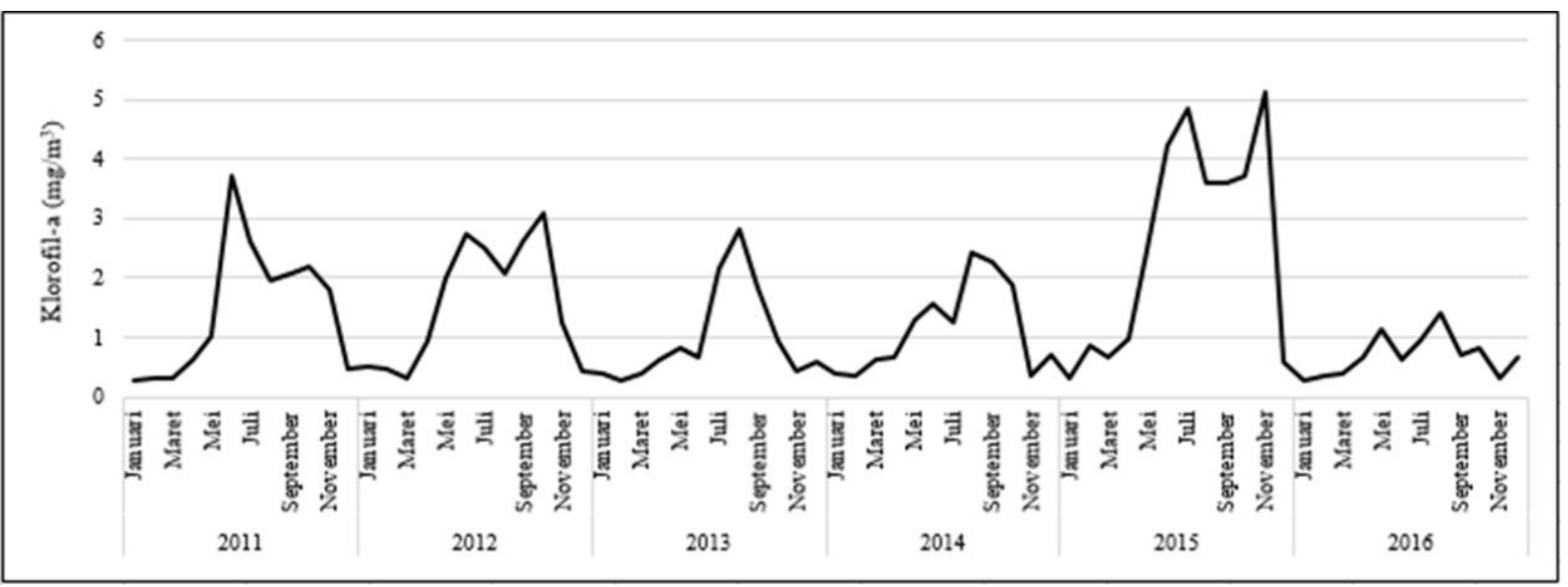

Gambar 3. Fluktuasi Temporal Konsentrasi Klorofil-a pada tahun 2011-2016

cenderung berada di belahan bumi selatan pada bulan Desember-April, yang menyebabkan SPL di perairan Indonesia pada belahan selatan khatulistiwa memiliki SPL yang lebih tinggi.

Nilai SPL musim timur pada tahun 2011-2016 menunjukkan nilai rata-rata SPL terendah. Rendahnya nilai SPL musim timur pada tahun 2011-2016, karena berhembusnya angin munson tenggara di perairan Selat Bali yang menyebabkan arus katulistiwa selatan mendorong massa air bersuhu tinggi kearah barat, sehingga menyebabkan naikknya massa air yang bersuhu rendah menuju kepermukaan perairan, dimana peristiwa ini dikenal dengan fenomena upwelling (Ridha et al., 2013).

3.1.2 Fluktuasi Temporal Konsentrasi Klorofil-a pada Perairan Selat Bali Tahun 2011-2016

Musim timur (Juni-Agustus) menunjukkan nilai rata-rata konsentrasi klorofil-a tertinggi, sedangkan pada musim barat (Desember-Februari) menunjukkan nilai rata-rata terendah. Variabiltas temporal konsentrasi klorofil-a di perairan Selat Bali tahun 2011-2016 ditampilkan pada Gambar 3.

Pada musim barat tahun 2011 sampai 2016, nilai konsentrasi klorofil-a bulan Januari berkisar 0.18$0.67 \mathrm{mg} / \mathrm{m}^{3}$ dengan rata-rata sebesar $0.35 \mathrm{mg} / \mathrm{m}^{3}$, nilai konsentrasi klorofil-a pada bulan Februari berkisar $0.19-1.57 \mathrm{mg} / \mathrm{m}^{3}$ dengan rata-rata sebesar $0.44 \mathrm{mg} / \mathrm{m}^{3}$ dan nilai konsentrasi klorofil-a pada bulan Deseber berkisar 0.17-1.57 $\mathrm{mg} / \mathrm{m}^{3}$ dengan rata-rata sebesar $0.56 \mathrm{mg} / \mathrm{m}^{3}$. Rata-rata nilai konsentrasi klorofil-a pada musim barat tahun 2011-2016 sebesar $0.46 \mathrm{mg} / \mathrm{m}^{3}$.

Pada musim peralihan I tahun 2011-2016, nilai konsentrasi klorofil-a bulan Maret berkisar 0.19$1.07 \mathrm{mg} / \mathrm{m}^{3}$ dengan rata-rata sebesar $0.47 \mathrm{mg} / \mathrm{m}^{3}$, nilai konsentrasi klorofil-a pada bulan April berkisar $0.27-1.58 \mathrm{mg} / \mathrm{m}^{3}$ dengan rata-rata sebesar $0.77 \mathrm{mg} / \mathrm{m}^{3}$, dan nilai konsentrasi klorofil-a pada bulan Mei berkisar 0.57-3.94 mg/m³ dengan rata- 
rata sebesar $1.47 \mathrm{mg} / \mathrm{m}^{3}$. Rata-rata nilai konsentrasi klorofil-a pada musim peralihan I tahun 2011-2016 sebesar $0.9 \mathrm{mg} / \mathrm{m}^{3}$.

Pada musim timur tahun 2011-2016, nilai konsentrasi klorofil-a bulan Juni berkisar 0.48-5.13 $\mathrm{mg} / \mathrm{m}^{3}$ dengan rata-rata sebesar $2.25 \mathrm{mg} / \mathrm{m}^{3}$, nilai konsentrasi klorofil-a Juli berkisar 0.67-5.94 mg/m $\mathrm{m}^{3}$ dengan rata-rata sebesar $2.40 \mathrm{mg} / \mathrm{m}^{3}$, dan nilai konsentrasi klorofil-a bulan Agustus berkisar 1.15$7.08 \mathrm{mg} / \mathrm{m}^{3}$ dengan rata-rata sebesar $2.38 \mathrm{mg} / \mathrm{m}^{3}$. Rata-rata nilai konsentrasi klorofil-a pada musim timur (Juni - Agustus) tahun 2011-2016 sebesar 2.3 $\mathrm{mg} / \mathrm{m}^{3}$.

Pada musim peralihan II tahun 2011-2016, nilai konsentrasi klorofil-a pada bulan September berkisar $0.61-4.53 \mathrm{mg} / \mathrm{m}^{3}$ dengan rata-rata sebesar $2.10 \mathrm{mg} / \mathrm{m}^{3}$, nilai konsentrasi klorofil-a pada bulan Oktober berkisar 0.14-5.64 mg/ $\mathrm{m}^{3}$ dengan rata-rata sebesar $2.10 \mathrm{mg} / \mathrm{m}^{3}$, dan nilai konsentrasi klorofil-a pada bulan November berkisar $0.14-7.76 \mathrm{mg} / \mathrm{m}^{3}$ dengan rata-rata sebesar $1.48 \mathrm{mg} / \mathrm{m}^{3}$. Rata-rata nilai konsentrasi klorofil-a pada musim peralihan II tahun 2011-2016 sebesar $1.9 \mathrm{mg} / \mathrm{m}^{3}$.

Konsentrasi klorofil-a pada perairan Selat Bali di setiap musim selama tahun 2011-2016 mengalami fluktuasi. Tingginya nilai rata-rata konsentrasi klorofil-a pada musim timur tahun 2011-2016, karena adanya pengaruh dari fenomena upwelling yang terjadidi perairan selatan jawa dan Selat Bali (Ridha et al., 2013; Setiawati et al., 2015). Fenomena upwelling menyebabkan terjadinya penurunan SPL dan tingginya kandungan unsur hara yang kaya akan nutrien (nitrat dan fosfat) menuju ke permukaan perairan, sehingga nutrien dalam jumlah yang tinggi akan diikuti dengan meningkatnya kandungan klorofil-a pada daerah perairan tersebut (Kemili dan Putri, 2012).
Nilai konsentrasi klorofil-a musim barat pada tahun 2011-2016 menunjukkan nilai rata-rata terendah. Rendahnya nilai konsentrasi klorofil-a pada musim barat, disebabkan oleh faktor cuaca yang buruk sehingga itensitas penyinaran matahari menjadi minim/berkurang di perairan laut. Mnusim barat merupakan musim yang membawa banyak hujan. Pengaruh curah hujan yang cukup tinggi pada perairan, menyebabkan penyinaran sinar matahari yang masuk keperairan menjadi terhambat untuk efektivitas fotosintesis dari fitoplankton. Organisme fitoplankton yang berada pada perairan mempunyai pigmen hijau berupa klorofil yang digunakan dalam proses fotosintesis. Oleh karena itu penurunan konsentrasi klorofil-a pada musim barat disebabkankarena adanya pengaruh dari penyinaran sinar matahari yang sedikit didapat oleh fitoplankton.

3.1.3. Fluktuasi Temporal Hasil Tangkapan Ikan Tongkol pada Perairan Selat Bali Tahun 2011-2016

Variabiltas temporal hasil tangkapan ikan tongkol pada perairan Selat Bali tahun 2011-2016 ditampilkan pada Gambar 4. Pada musim barat tahun 2011-2016, nilai hasil tangkapan ikan tongkol bulan Januari berkisar 0-9.612 $\mathrm{kg}$ dengan nilai rata-rata sebesar $1.554,25 \mathrm{~kg}$, nilai hasil tangkapan ikan tongkol pada bulan Februari berkisar 0-36.574 $\mathrm{kg}$ dengan nilai rata-rata sebesar $3.916,47 \mathrm{~kg}$, dan nilai hasil tangkapan ikan tongkol pada bulan Desember berkisar 0-219.177kg dengan nilai rata-rata sebesar $17.989,36 \mathrm{~kg}$. Pada musim barat tahun 2011-2016 rata-rata hasil tangkapan ikan tongkol sebesar $8.521,36 \mathrm{~kg}$.

Pada musim peralihan I tahun 2011 sampai 2016, nilai hasil tangkapan ikan tongkol bulan

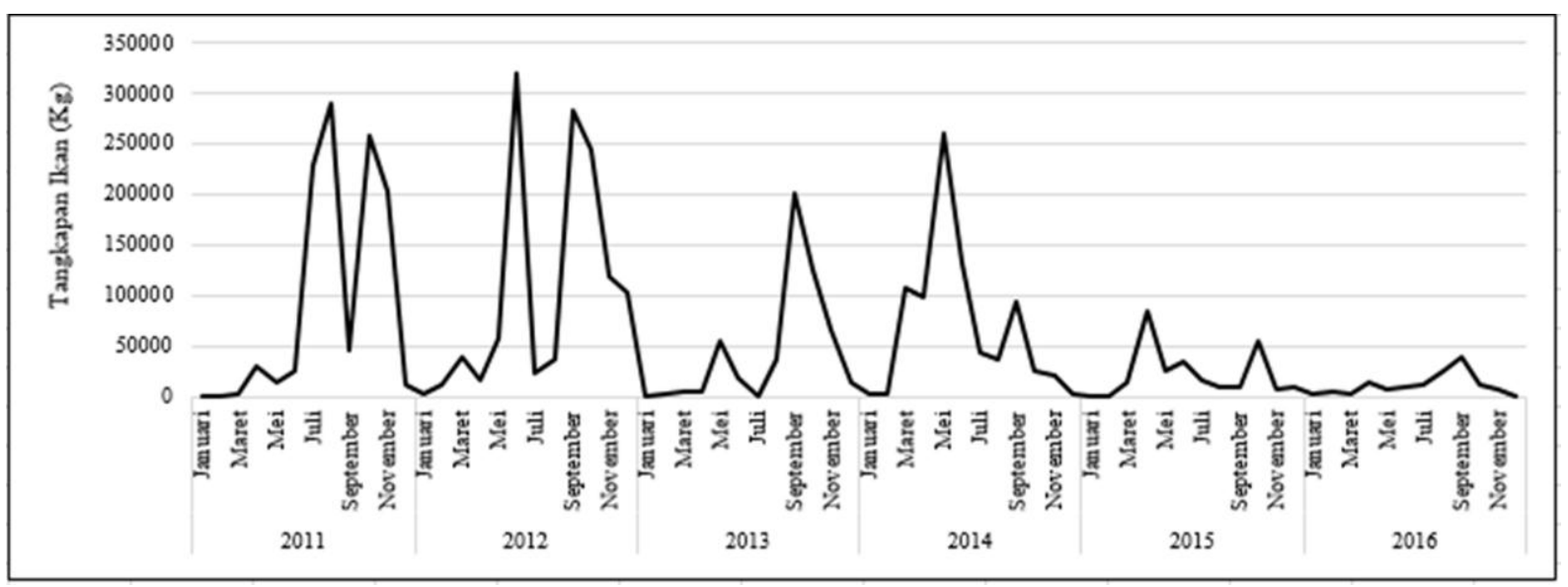

Gambar 4. Fluktuasi Temporal Hasil Tangkapan Ikan Tongkol pada tahun 2011-2016 
Maret berkisar 0-176.454 kg dengan nilai rata-rata sebesar 28.223,8 kg, nilai hasil tangkapan ikan tongkol pada bulan April berkisar 1.087-230.014 kg dengan nilai rata-rata hasil sebesar $41.932,8 \mathrm{~kg}$, dan nilai hasil tangkapan ikan tongkol pada bulan Mei berkisar 0-362.361 kg dengan nilai rata-rata sebesar 70.092,7 kg. Pada musim peralihan I tahun 2011-2016 rata-rata hasil tangkapan ikan tongkol sebesar 46.749,8 kg.

Pada musim timur tahun 2011-2016 nilai hasil tangkapan ikan tongkol bulan Juni berkisar 0$559.204 \mathrm{~kg}$ dengan nilai rata-rata sebesar 89.589,6 $\mathrm{kg}$, nilai hasil tangkapan ikan tongkol pada bulan Juli berkisar $0-407.628 \mathrm{~kg}$ dengan nilai rata-rata sebesar $54.323,7 \mathrm{~kg}$, dan nilai hasil tangkapan ikan tongkol pada bulan Agustus berkisar 200$609.984 \mathrm{~kg}$ dengan nilai rata-rata sebesar $72.475 \mathrm{~kg}$. Pada musim timur tahun 2011-2016 rata-rata hasil tangkapan ikan tongkol sebesar $72.129,6 \mathrm{~kg}$.

Pada musim peralihan II dari tahun 2011-2016 nilai hasil tangkapan ikan tongkol bulan September berkisar 2.101-613.694 kg dengan nilai rata-rata sebesar $118.100,8 \mathrm{~kg}$, nilai hasil tangkapan ikan tongkol pada bulan Oktober berkisar 2040$557.955 \mathrm{~kg}$ dengan nilai rata-rata sebesar 119.933,8 $\mathrm{kg}$, dan nilai hasil tangkapan ikan tongkol pada bulan November berkisar 0-380.294 kg dengan nilai rata-rata sebesar $72.404 \mathrm{~kg}$. Pada musim peralihan II tahun 2011-2016 rata-rata hasil tangkapan ikan tongkol sebesar 102.369,7 kg.

Hasil tangkapan ikan tongkol di perairan Selat Bali pada setiap musim selama tahun 2011-2016 mengalami fluktuasi. Nilai hasil tangkapan ikan tongkol rata-rata pada musim peralihan II menunjukkan nilai tertinggi dan pada musim barat menunjukkan nilai terendah. Tinggi dan rendahnya rata-rata hasil tangkapan ikan tongkol diduga adanya pengaruh dari konsentrasi klorofila di perairan. Jennings and Brander (2010) menyatakan bahwa meningkatnya konsentrasi klorofil-a akan diikuti dengan meningkatnya hasil tangkapan ikan tongkol. Menurut Prayoga et al. (2017) perairan Selat Bali menunjukkan adanya jeda waktu (time lag) antara hasil tangkapan ikan tongkol dengan konsentrasi klorofil-a. Nybakken (1992) menyatakan bahwa ikan pelagis besar (ikan tongkol) perlu memerlukan jeda waktu dalam memanfaatkan jumlah klorofil-a di perairan, dimana fitoplankton terlebih dahulu akan dimanfaatkan oleh hewan konsumen I (zooplankton) yang kemudian dimangsa oleh konsumen II (ikan-ikan kecil) dan kemudian akan dimangsa oleh konsumen III yaitu ikan tongkol.

3.2 Hubungan SPL, Konsentrasi Klorofil-a dan Hasil Tangkapan Ikan Tongkol pada Perairan Selat Bali pada Tahun 2011-2016

\subsubsection{Hubungan SPL terhadap Hasil Tangkapan} Ikan Tongkol

Hubungan antara SPL terhadap hasil tangkapan ikan tongkol di perairan Selat Bali ditampilkan pada Gambar 5. Hubungan antara SPL terhadap hasil tangkapan ikan tongkol menunjukkan koefisien korelasi sebesar -0,31. Nilai korelasi tersebut menunjukkan adanya hubungan linier negatif (berbanding terbalik) antara SPL terhadap hasil tangkapan ikan tongkol pada perairan Selat

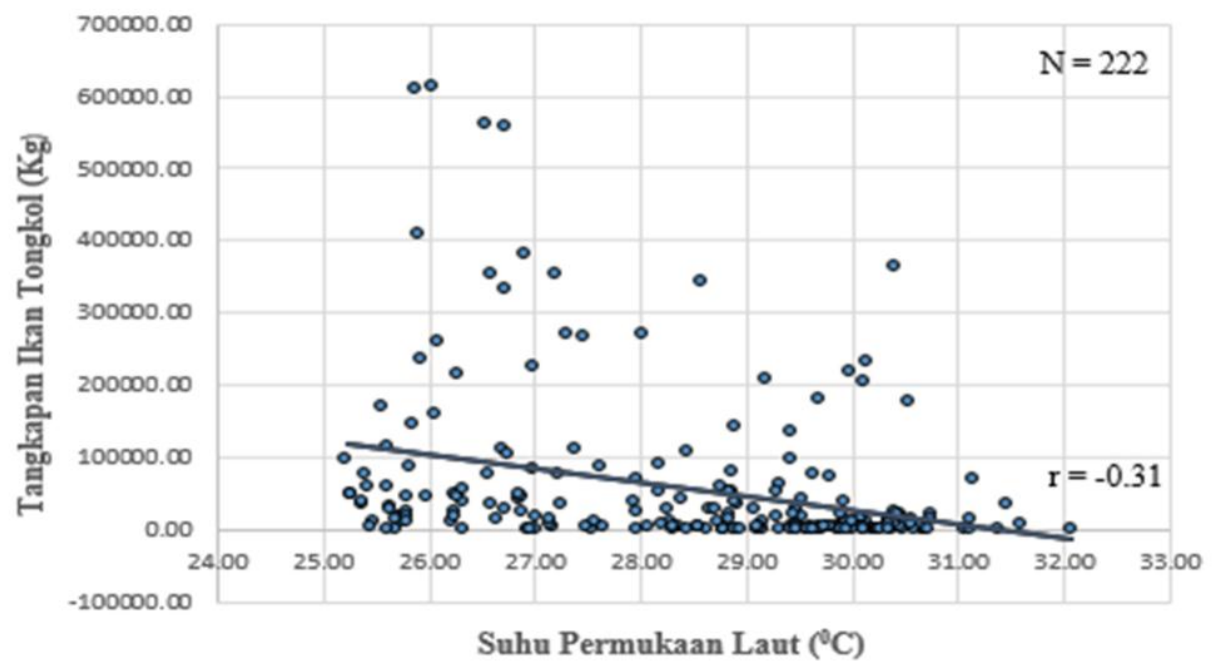

Gambar 5. Hubungan SPL terhadap hasil tangkapan ikan tongkol pada tahun 2011-2016 
Bali, dimana semakin tinggi nilai SPL akan diikuti dengan menurunnya hasil tangkapan ikan tongkol. Nilai korelasi SPL dengan hasil tangkapan ikan tongkol termasuk kedalam kategori rendah. Pada uji validitas didapatkan bahwa nilai $r$ hitung (0.31) $>\mathrm{r}$ tabel $(0,13)$, maka hubungan SPL terhadap hasil tangkapan ikan tongkol menunjukkan adanya hubungan signifikan.

Pada Gambar 5 menunjukkan hubungan linier negatif, dimana hasil tangkapan ikan tongkol paling banyak diperoleh saat SPL mengalami penuruan pada kisaran $25^{\circ}-27^{\circ} \mathrm{C}$. Suhu perairan yang berada pada kisaran antara $20^{\circ}-28^{\circ} \mathrm{C}$ merupakan suhu perairan yang optimum bagi ikan tongkol untuk beraktifitas sehingga ikan akan berada dipermukaan sampai kedalaman 40 meter. Oleh karena itu hasil tangkapan ikan tongkol akan menunjukkan peningkatan pada saat suhu mengalami penurunan, sedangkan tangkapan ikan tongkol menurun pada suhu $32^{\circ} \mathrm{C}$. Hal ini diduga karena, kumpulan ikan tongkol akan berenang lebih dalam pada saat suhu perairan berkisar antara $31^{\circ} \mathrm{C}$ dan $32^{\circ} \mathrm{C}$ sehingga alat tangkap ikan tidak akan dapat menjangkaunya. Menurut Adnan (2010) SPL yang tinggi pada suatu perairan menghasilkan tangkapan ikan tongkol yang relatif rendah, begitu juga sebaliknya.

\subsubsection{Hubungan Konsentrasi klorofil-a terhadap Hasil Tangkapan Ikan Tongkol}

Hubungan antara konsentrasi klorofil-a dengan hasil tangkapan ikan tongkol tahun 2011-2016 ditampilkan pada Gambar 6. Hubungan konsentrasi klorofil-a terhadap hasil tangkapan ikan tongkol menunjukkan koefisien korelasi sebesar 0,19. Nilai korelasi tersebut menunjukkan adanya hubungan linier positif (berbanding lurus) antara konsentrasi klorofil-a dengan hasil tangkapan ikan tongkol. Semakin tingginya nilai konsentrasi klorofil-a akan diikuti dengan meningkatnya hasil tangkapan ikan tongkol. Nilai korelasi konsentrasi klorofil-a terhadap hasil tangkapan ikan tongkol termasuk dalam kategori sangat rendah. Pada uji validitas didapatkan bahwa nilai $r$ hitung $(0.19)>r$ tabel $(0,13)$, maka hubungan konsentrasi klorofil-a terhadap hasil tangkapan ikan tongkol menunjukkan adanya hubungan signifikan.

Melimpahnya kandungan konsentrasi klorofil-a pada perairan akan meningkatan produktifitas plankton, sehingga terjadinya rantai makanan yang menunjang produktifitas ikan di perairan (Saba et al., 2011; Sadly et al., 2009). Kelimpahan ikan dapat diprediksi dengan mengetahui konsentrasi klorofil-a (fitoplankton) pada perairan (Hazen et al., 2013; Lanz et al., 2009). Peningkatan nilai konsentrasi klorofil-a tidak secara bersamaan diikuti dengan peningkatan hasil tangkapan ikan tongkol (Prayoga et al., 2017). Hal ini dikarenakan adanya jeda waktu (time lag) antara konsentrasi klorofil-a dengan tangkapan ikan-ikan besar (Prastianto, 2016). Konsentrasi klorofil-a (fitoplankton) yang terdapat di perairan terlebih akan konsumsi oleh hewan konsumen I (zooplankton), kemudian konsumen II (ikan-ikan kecil) akan mengkonsumsinya, setelah itu kemudian ikan-ikan kecil akan dimangsa konsumen III (ikan tongkol) dan selanjutnya ikan tongkol akan dimangsa oleh konsumen tingkat IV

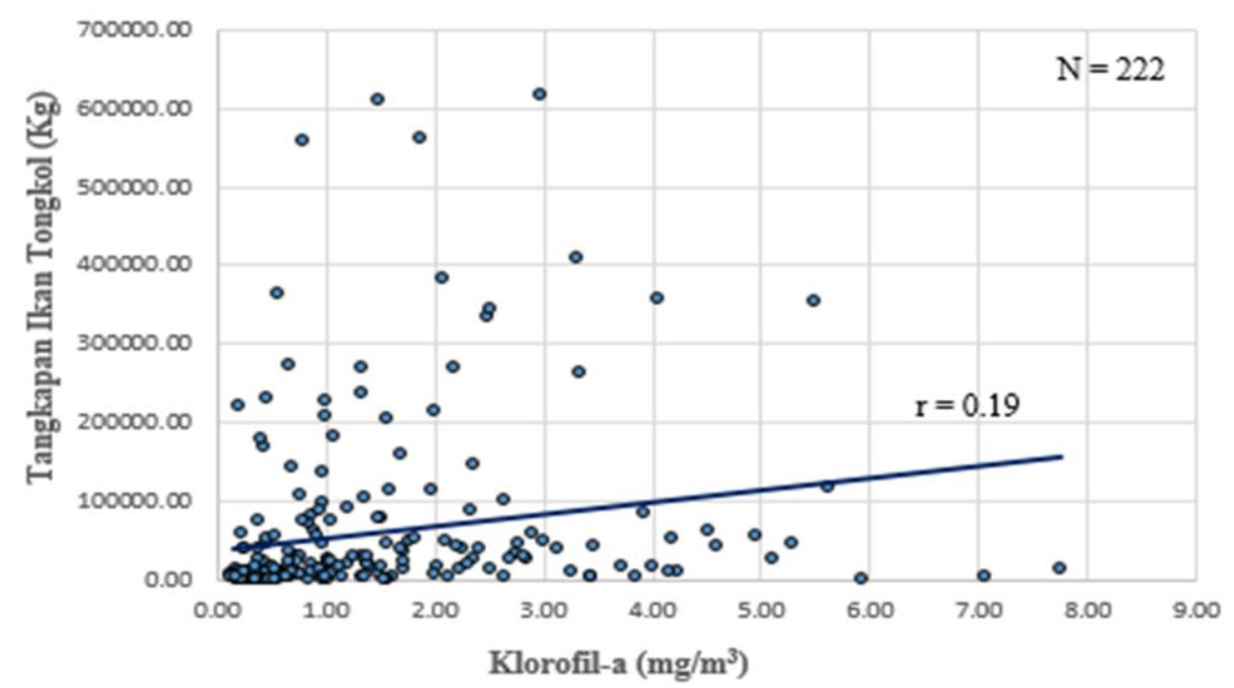

Gambar 6. Hubungan konsentrasi klorofil-a terhadap hasil tangkapan ikan tongkol pada tahun 2011-2016 


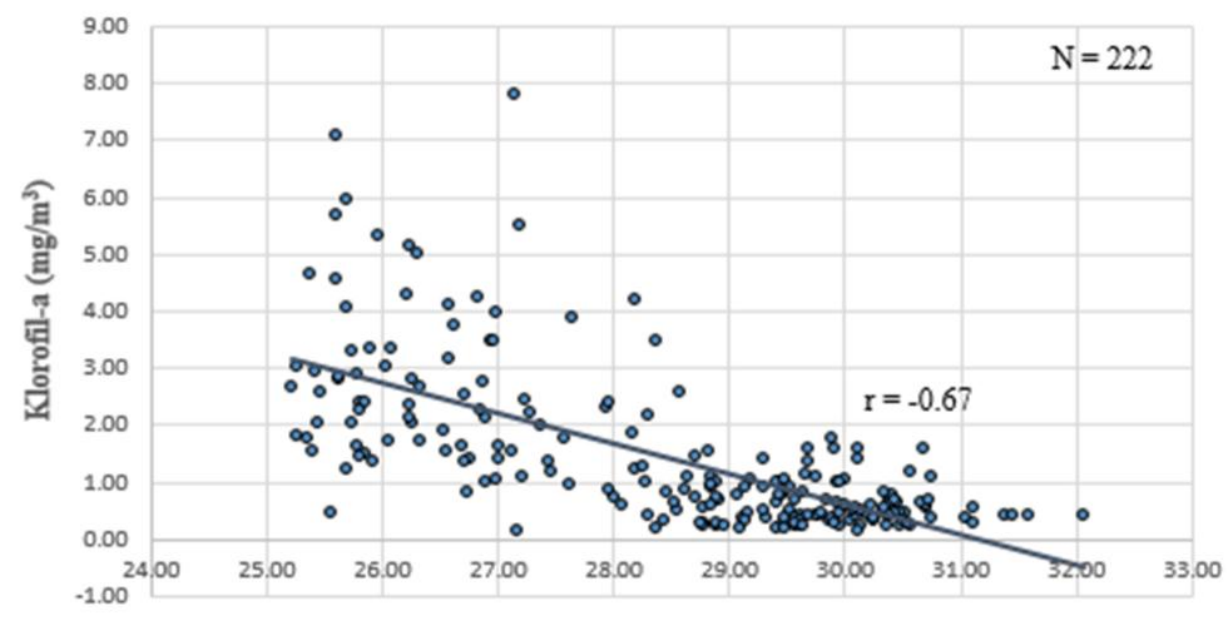

Suhu Permukaan Laut $\left({ }^{\circ} \mathrm{C}\right)$

Gambar 7. Hubungan SPL terhadap konsentrasi klorofil-a pada tahun 2011-2016

(hiu) (Nybakken, 1992).

\subsubsection{Hubungan SPL terhadap Konsentrasi klorofil-a}

Hubungan SPL terhadap konsentrasi klorofil-a di perairan Selat Bali tahun 2011 - 2016 ditunjukkan pada Gambar 7. Hubungan SPL terhadap konsentrasi klorofil-a menunjukkan koefisien korelasi sebesar -0,67. Nilai korelasi tersebut menunjukkan adanya hubungan linier negatif (berbanding terbalik) antara SPL terhadap konsentrasi klorofil-a. Semakin tingginya nilai SPL akan diikuti dengan menurunnya konsentrasi klorofil-a. Nilai SPL terhadap konsentrasi klorofila termasuk dalam kategori kuat. Pada uji validitas didapatkan bahwa nilai $\mathrm{r}$ hitung $(0.67)>\mathrm{r}$ tabel $(0,13)$, maka hubungan SPL terhadap konsentrasi klorofil-a menunjukkan adanya hubungan signifikan.

Peningkatan dan penurunan fluktuasi SPL dan konsentrasi klorofil-a yang secara bersamaan dikarenakan pada saat itu kondisi suhu yang meningkat akan menyebabkan kurang optimalnya fitoplankton (klorofil-a) untuk berkembang pada perairan, sehingga jumlah fitoplankton akan menurun, akan tetapi pada saat suhu menurun yang diakibatkan oleh proses upwelling menyebabkan suhu menjadi optimal bagi berkembangnya fitoplankton dengan rata-rata suhu $25^{\circ} \mathrm{C}$. Penelitian Inaku (2015) menyatakan bahwa menurunnya SPL akan diikuti dengan meningkatnya konsentrasi klorofil-a, dimana dapat dikatakan bahwa meningkatnya nilai SPL di perairan Selat Bali akan diikuti dengan menurunnya konsentrasi klorofil-a.

\section{Kesimpulan}

Secara temporal tahun 2016 menunjukkan SPL tertinggi. Pada musiman, SPL tertinggi terjadi pada musim peralihan I dan terendah pada musim timur. Konsentrasi klorofil-a tertinggi terjadi pada tahun 2015. Pada musiman, konsentrasi klorofil-a tertinggi terjadi musim timur dan terendah pada musim barat. Hasil tangkapan ikan tongkol tertinggi terjadi pada tahun 2011. Pada musiman, hasil tangkapan ikan tongkol tertinggi pada musim peralihan II dan terendah pada musim barat. Hubungan antara SPL, konsentrasi klorofil-a terhadap hasil tangkapan ikan tongkol menunjukkan korelasi rendah. Sedangkan antara SPL terhadap konsentrasi klorofil-a menunjukkan korelasi kuat. Pada ketiga hubungan tersebut menunjukkan adanya hubungan yang signifikan.

\section{Ucapan Terimakasih}

Penulis mengucapkan terimakasih kepada kepala Pelabuhan Perikanan Nusantara (PPN) Pengambengan Jembrana dan Kepala Pangkalan Pendaratan Ikan (PPI) Kuta dan Kuta Selatan yang telah memberikan data hasil tangkapan ikan tongkol. Serta terimakasih sebesar-besarnya kepada Fakultas Kelautan dan Perikanan Universitas Udayana atas fasilitas yang telah diberikan. 


\section{Daftar Pustaka}

Adnan, A. (2010). Analisis SPL dan klorofil-a data inderaja hubungannya dengan hasil tangkapan ikan tongkol (Euthynnus affinis) di perairan Kalimantan Timur. Jurnal "Amanisal" PSP FPIK Unpatti-Ambon, 1(1), 1-12.

Akhlak, M. A., Supriharyono, S., \& Hartoko, A. (2015). Hubungan variabel suhu permukaan laut, klorofil-a dan hasil tangkapan kapal purse seine yang didaratkan di TPI Banjomulyo Juwana, Pati. Journal of Maquares Management of Aquatic Resources, 4(4), 128135.

Ashari, F., Redjeki, S., \& Kunarso, K. (2014). Keterkaitan jumlah tangkapan ikan pelagis kecil dengan distribusi klorofil-a dan suhu permukaan laut menggunakan citra modis di laut Jawa dan Selat Makassar. Journal of Marine Research, 3(3), 366-373.

Ekayana, I M., Karang, I W. G. A., As-syakur, A. R., Jatmiko, I., \& Novianto, D. (2017). Hubungan hasil tangkapan ikan tuna selama februari-maret 2016 dengan konsentrasi klorofil-a dan SPL dari data penginderaan jauh di perairan selatan Jawa-Bali, Bali. Jurnal of Marine and Aquatic Sciences, 3(1), 19-29.

Ferraro, V., Carvalho, A. P., Piccirillo, C., Santos, M. M., Castro, P. M., \& Pintado, M. E. (2013). Extraction of high added value biological compounds from sardine, sardine-type fish and mackerel canning residues - a review. Materials Science and Engineering: C, 33(6), 3111-3120.

Hazen, E.L., Jorgensen, S., Rykaczewski, R.R., Bograd, S.J., Foley, D.G., Jonsen, I.D., Shaffer, S.A., Dunne, J.P., Costa, D.P., Crowder, L.B., Block, B.A. (2013). Predicted habitat shifts of Pacific top predators in a changing climate. Nature Climate Change, 3(3), 234.

Inaku, F. (2015). Analisis pola sebaran dan perkembangan area upwelling di bagian selatan Selat Makassar. Torani. Jurnal Ilmu Kelautan dan Perikanan, 25(2), 67-74.

Jennings, S., \& Brander, K. (2010). Predicting the effects of climate change on marine communities and the consequences for fisheries. Journal of Marine Systems, 79(3), 418-426.

Kemili, P., \& Putri, M. R. (2012). Pengaruh durasi dan intensitas upwelling berdasarkan anomali suhu permukaan laut terhadap variabilitas produktivitas primer di perairan Indonesia. Jurnal Ilmu dan Teknologi Kelautan Tropis, 4(1), 66-79.

Lanz, E., Martinez, M. N., Martinez, J. L., \& Dworak, J. A. (2009). Small pelagic fish catches in the Gulf of California associated with sea surface temperature and chlorophyll. California Cooperative Oceanic Fisheries Investigations Reports, 50, 134-146.

Mujib, Z., Boesno, H., \& Fitri, A. D. P. (2013). Pemetaan sebaran ikan tongkol (Euthynnus $s p$ ) dengan data klorofil-a citra modis pada alat tangkap payang
(Danish-seine) di perairan teluk Pelabuhanratu, Sukabumi, Jawa Barat. Journal of Fisheries Resources Utilization Management and Technology, 2(2), 150-160.

Nuris, R. (2014). Komparasi pendugaan kandungan klorofil-a dari citra satelit NPP dan aqua-modis di perairan selatan Jawa [Skripsi]. Bogor, Indonesia: Departemen Ilmu dan Teknologi Kelautan, Fakultas Perikanan dan Ilmu Kelautan, Institut Pertanian Bogor (IPB).

Nybakken. (1992). Biologi Laut. Jakarta, Indonesia: PT. Gramedia.

Padmaningrat, K. B., Karang, I W. G. A., \& As-syakur, A. R. (2017). Aplikasi sistem informasi geografis (SIG) dan penginderaan jauh untuk pemetaan daerah penangkapan ikan tuna mata besar di selatan Jawa dan Bali. Jurnal of Marine and Aquatic Sciences, 3(1), 7083.

Prastianto, F. (2016). Analisis dan pemetaan konsentrasi klorofil-a di selat Makassar sebagai acuan untuk pembuatan peta prakiraan daerah penangkapan ikan dengan menggunakan citra satelit aqua-modis. Jurnal Ilmu Perikanan Tropis, 21(2), 024-031.

Pratiwi, N. T. M., Wulandari, D. Y., Ayu, I. P., \& Iswantari, A. (2017). Diversity and Spatial Distribution of Plankton in Connected Waters of Bali Strait, Between Eastern Part of Java and Western Part of Bali Island. IOP Conference Series: Earth and Environmental Science, 54(1), 012090.

Prayoga, S., Putra, I D. N. N., \& Dirgayusa, I G. N. P. (2017). Pengaruh sebaran konsentrasi klorofil-a berdasarkan citra satelit terhadap hasil tangkapan ikan tongkol di perairan Selat Bali. Jurnal of Marine and Aquatic Sciences, 3(1), 30-46.

Putri, G. A., Zainuri, M., \& Priyono, B. (2016). Sebaran ortofosfat dan klorofil-a di perairan Selat Karimata. Buletin Oseanografi Marina, 5(1), 44-51.

Ridha, U., Muskananfola, M. R., \& Hartoko, A. (2013). Analisa sebaran tangkapan ikan lemuru (Sardinella lemuru) berdasarkan data satelit suhu permukaan laut dan klorofil-a di perairan Selat Bali. Diponegoro Journal of Maquares Management of Aquatic Resources, 2(4), 53-60.

Saba, V. S.; Friedrichs, M. A. M.; Antoine, D.; Armstrong, R. A.; Asanuma, I.; Behrenfeld, M. J., Ciotti, A. M., Dowell, M., Hoepffner, N., Hyde, K. J. W., Ishizaka, J.; Kameda, T.; Marra, J.; Mélin, F.; Morel, A.; O'Reilly, J.; Scardi, M.; Smith, W. O., Jr., Smyth, T. J., Tang, S., Uitz, J., Waters, K., \& Westberry, T. K. (2011). An evaluation of ocean color model estimates of marine primary productivity in coastal and pelagic regions across the globe. Biogeosciences, 8, 489-503.

Sadly, M., Hendiarti, N., Sachoemar, S. I., \& Faisal, Y. (2009). Fishing ground prediction using a knowledgebased expert system geographical information system model in the South and Central Sulawesi coastal waters of Indonesia. International journal of remote sensing, 30(24), 6429-6440. 
Setiawati, M. D., Sambah, A. B., Miura, F., Tanaka, T., \& As-syakur, A. R. (2015). Characterization of bigeye tuna habitat in the Southern Waters off Java-Bali using remote sensing data. Advances in Space Research, 55(2), 732-746.

Syafruddin, S. \& Zainuddin, M. (2008). Prediksi daerah penangkapan ikan cakalang berdasarkan kondisi oseanografi di perairan kabupaten Takalar dan sekitarnya. Jurnal Sains E Teknologi, 8(2), 158 - 162.

Tangke, U., Karuwal, J. C., Zainuddin, M., \& Mallawa, A. (2015). Sebaran suhu permukaan laut dan klorofil-a pengaruhnya terhadap hasil tangkapan yellowfin tuna (Thunnus albacares) di perairan laut Halmahera bagian selatan. Jurnal IPTEKS PSP, 2(3), 248-260.

Walpole, R. E. (1995). Pengantar statistika (Edisi Ketiga). PT Gramedia Pustaka Utama, Jakarta.

Zarochman, K. (2012). A brief review Indo-Pacific king mackerel (Scomberomorus guttatus) in Indonesia. In Second Working Party on Neritic Tunas (IOTC-2012WPNTO2-19). Penang, Malaysia, 19-21 November 2012 (pp. 1-9).

(C) 2017 by the authors; licensee Udayana University, Indonesia. This article is an open access article distributed under the terms and conditions of the Creative Commons Attribution license (http://creativecommons.org/licenses/by/3.0/). 